\title{
Lipoprotein Lipase Regulation by Insulin and Glucocorticoid in Subcutaneous and Omental Adipose Tissues of Obese Women and Men
}

Susan K. Fried, Colleen D. Russell, Nancy L. Grauso, and Robert E. Brolin

Department of Nutritional Sciences, Cook College, Rutgers University, and Department of Surgery, University of Medicine and Dentistry of New Jersey, Robert Wood Johnson Medical School, New Brunswick, New Jersey 08903

\begin{abstract}
There are marked variations in the activity of lipoprotein lipase (LPL) among adipose depots, particularly in women. Consistent with data on LPL activity, the level of expression of LPL mRNA was lower in omental (OM) than subcutaneous (SQ) adipose tissue of women. To investigate the cellular basis of these differences, $O M$ and $S Q$ adipose tissues obtained at surgery from obese men and women were placed in organ culture for $7 \mathrm{~d}$ with varying concentrations of insulin and dexamethasone. Insulin increased levels of LPL mRNA and LPL activity in abdominal SQ but not $O M$ adipose tissue. Dexamethasone also increased LPL mRNA and LPL activity, and these effects were more marked in the OM adipose tissue, particularly in men. When insulin and dexamethasone were added together, synergistic increases in LPL activity were seen in both depots, and this was in part explained at the level of LPL mRNA. The SQ depot was more sensitive to the effects of submaximal doses of dexamethasone in the presence of insulin. The maximum activity of LPL induced by insulin or insulin plus dexamethasone was higher in the SQ than in the OM depot of women, and this was associated with higher levels of LPL mRNA. Rates of LPL synthesis paralleled LPL mRNA levels. These data show that insulin and glucocorticoids influence human adipose tissue LPL activity at the level of LPL gene expression, as well as posttranslationally, and that responsiveness to these hormonal effects is dependent on adipose depot and gender. (J. Clin. Invest. 1993. 92:2191-2198.) Key words: adipose tissue • insulin • glucocorticoids • dexamethasone • lipoprotein lipase
\end{abstract}

\section{Introduction}

The regional distribution of fat in humans varies as a function of gender, hormonal status, and genetic predisposition (1). With increasing fatness, men deposit more fat in intraabdominal fat depots than women, and women with upper body obesity generally deposit more intraabdominal fat than women with lower body obesity $(2,3)$.

In both sexes, the size of intraabdominal fat stores, independent of total body fatness, is highly correlated with metabolic abnormalities associated with obesity, including low HDL levels, hypertriglyceridemia, and glucose intolerance $(1,4,5)$.

Address correspondence to Dr. Susan K. Fried, Department of Nutritional Sciences, Cook College, Box 231, Rutgers University, New Brunswick, NJ 08903-0231.

Received for publication 24 November 1992 and in revised form 18 May 1993.

J. Clin. Invest.

(c) The American Society for Clinical Investigation, Inc.

$0021-9738 / 93 / 11 / 2191 / 08 \quad \$ 2.00$

Volume 92, November 1993, 2191-2198
Though heterogeneity in the metabolic activities of adipocytes from different fat depots has been extensively documented (6), the cellular and molecular mechanisms regulating regional fat deposition are not fully understood. Recently, however, Arner and colleagues (7-9) have described differences among subcutaneous depots in the expression of mRNAs for a number of adipocyte proteins.

One important determinant of triglyceride storage in the adipocyte is the activity of the enzyme lipoprotein lipase $(\mathrm{LPL})^{1}(10)$. LPL catalyzes the hydrolysis of circulating triglycerides to free fatty acids, which can then be reesterified and stored in the adipocyte. Regional variations in adipose tissue LPL activity have been demonstrated, and these differences closely parallel regional variations in fat cell size (11-13). We have previously shown that omental (OM) adipose tissue from women has smaller adipocytes with lower LPL activity than subcutaneous (SQ) depots, and that such regional differences are not apparent in men (11). In both sexes, OM adipose tissue, compared with SQ abdominal adipose tissue, is more responsive to lipolytic effects of catecholamines, less sensitive to insulin's (Ins's) antilipolytic action, and has a higher density of glucocorticoid receptors $(8,14-16)$.

An important role for glucocorticoids in enhancing central fat accumulation is suggested by the fact that the hypercortisolemia of Cushing syndrome is associated with a marked increase in the size of intraabdominal fat stores (17), and a specific increase in the activity of LPL in abdominal SQ compared with thigh fat (18).

The cellular and molecular mechanisms regulating LPL activity are not yet established, but transcriptional and posttranscriptional mechanisms ( $m$ RNA stability, translation, glycosylation, and activation ) appear to operate in different situations (10). Obesity- and meal-induced increases in LPL activity cannot be explained by variations in levels of LPL mRNA, and are apparently associated with increases in LPL-specific activity (19-21).

Mechanisms of the hormonal regulation of LPL have been studied using cultures of intact adipose tissue fragments and isolated adipocytes. In cultured abdominal SQ human adipose tissue, in contrast to results in cultured isolated $O M$ adipocytes $(20,22)$, Ins increases LPL activity by increasing LPL synthesis (23). Glucocorticoids added in the presence of Ins markedly increase LPL activity primarily by acting posttranslationally (23).

The major purpose of the present experiments was to investigate whether changes in the level of LPL mRNA parallel Ins and dexamethasone stimulation of LPL synthesis in cultured human adipose tissue. Because OM adipose tissue is less sensitive to Ins (14) and has a higher concentration of glucocorticoid receptors ( 8 ), we hypothesized that LPL regulation by Ins

1. Abbreviations used in this paper: Dex, dexamethasone; Ins, insulin; LPL, lipoprotein lipase; OM, omental; SQ, subcutaneous. 
and glucocorticoids would differ in this tissue. Adipose tissues from men and women were compared because regional variations in adipose tissue LPL activity are more prominent in women than men.

\section{Methods}

Organ culture of human adipose tissues. Human adipose tissue was obtained at surgery from SQ epigastric abdominal depots or the peripheral portion of the OM, as previously described (11). Most patients ( 38 women and $18 \mathrm{men}$ ) were undergoing gastrointestinal surgery for morbid obesity. Samples were also taken from several women $(n=6)$ who had lost substantial weight as a result of obesity surgery, and were undergoing additional surgery. Because the pattern of hormonal response between depots did not differ between the formerly obese and obese patients, all data were pooled. Samples of adipose tissue were processed as previously described and minced adipose tissue fragments were placed in serum-free M199 containing $25 \mathrm{mM}$ Hepes, Earles salts, with or without varying concentrations of insulin (0-7 nM; Humulin; Eli Lilly, Indianapolis, IN), or dexamethasone (0-250 nM), alone or in combination. Cultures were maintained for $7-8 \mathrm{~d}$, and the hormonesupplemented media were replenished every $2-3 \mathrm{~d}$. Cultures were used on days 6-8, after being refed the previous day $(23,24)$.

Measurement of LPL activity. LPL activity in heparin eluates from adipose tissue fragments was measured as previously described (11). 1 $\mathrm{U}$ of LPL activity is defined as catalyzing the release of $1 \mu \mathrm{mol}$ free fatty acid $/ \mathbf{h}$.

Biosynthetic labeling. Aliquots of cultured adipose tissue were incubated for a 30-min pulse period in minimal essential medium containing $\left[{ }^{35} \mathrm{~S}\right]$ methionine $(100 \mu \mathrm{Ci} / \mathrm{ml})$ and $\left[{ }^{35} \mathrm{~S}\right]$ cysteine $(100 \mu \mathrm{Ci} /$ $\mathrm{ml}$ ), and the same hormonal additions as during culture as described in detail previously (24). After homogenization in lysis buffer, incorporation of radioactivity into TCA-precipitable protein was measured, and volumes of homogenates representing equal TCA counts were used for immunoprecipitation of LPL as previously described (24), using a rabbit anti-human milk LPL antiserum (13).

$R N A$ extraction and Northern blotting. RNA was isolated from $\sim 1$ $\mathrm{g}$ of adipose tissue after homogenization in guanidinium isothiocyanate buffer, and phenol-chloroform extraction (25). To prepare RNA from isolated fat cells, cultured adipose tissue was digested with collagenase $(1 \mathrm{mg} / \mathrm{ml})$ as previously described (26), except that all buffers were supplemented with $100 \mathrm{nM}$ phenylisopropyladenosine. The lack of degradation of the RNA and equal loading of total RNA per lane were verified by visualization of ribosomal RNA subunits with ethidium bromide. Northern transfer and hybridization with cDNAs to human LPL, gamma actin, and $28 \mathrm{~S}$ ribosomal subunit were accomplished as previously described (24). After exposure of gels to x-ray film, autoradiographs were quantified by laser scanning densitometry (ultra scan XL; LKB Produkter, Bromma, Sweden).

Statistical analysis. All data are presented as means \pm SE. After log transformation of the data, individual means were compared by analysis of variance (ANOVA) with sex as a grouping variable, and repeated measures on hormone dose and depot using the program Systat. Individual means were compared by post hoc paired $t$ tests (depot effects,

Table I. Patient Characteristics

\begin{tabular}{lccccc}
\hline & & & \multicolumn{2}{c}{ FCW } \\
\cline { 4 - 6 } & BMI & Age & Omental & Subcutaneous \\
\hline & $k g / m^{2}$ & $y r$ & $\mu g$ lipid & $\mu g$ lipid \\
Women $(n=39-45)$ & $46 \pm 2$ & $39 \pm 2$ & $0.52 \pm 0.04^{*}$ & $0.64 \pm 0.06$ \\
Men $(n=17-18)$ & $50 \pm 3$ & $44 \pm 3$ & $0.81 \pm 0.11$ & $0.77 \pm 0.06$
\end{tabular}

Data are mean \pm SEM. FCW, fat cell weight. ${ }^{*} P<0.001$ compared with subcutaneous.
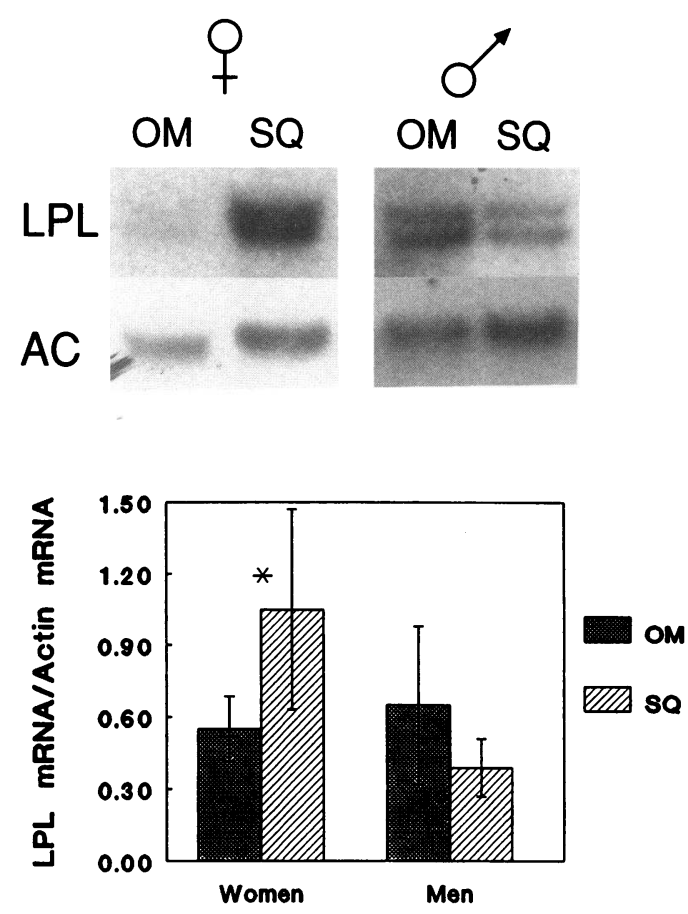

Figure 1. Levels of LPL mRNA in OM and abdominal SQ adipose tissues of men and women. Samples of adipose tissue from these two depots in the same patients were excised during surgery and immediately frozen. RNA was extracted, and 5- $\mu$ g aliquots were subjected to electrophoresis on formaldehyde gels, blotted onto nylon, and probed with ${ }^{32} \mathrm{P}$-labeled cDNA probes for human LPL and gammaactin. Equal loading of the gels was verified by ethidium bromide staining of total RNA. (Top) Representative Northern blot; (bottom) means \pm SEM of values of LPL/actin mRNA ratios from 12 women and 5 men. ${ }^{*} P<0.05$, site comparison.

dose effects) or independent $t$ test (gender effects), when ANOVA indicated significant overall effects $(P<0.05)(27)$.

\section{Results}

Patient characteristics. Patients were on average severely obese, as indicated by the average body mass index (BMI). The BMI and age of the men and women were comparable (Table I). In women, but not men, OM fat cells were significantly smaller than those from the SQ site (Table I).

Expression of LPL $M R N A$ in $O M$ and $S Q$ adipose tissues. To determine whether decreased LPL activity in OM adipose tissue of women (11) is associated with changes in levels of LPL mRNA, Northern analyses of RNA from OM and SQ adipose tissues was performed (Fig. 1). Levels of LPL relative to actin were significantly lower in $\mathrm{OM}$ than SQ adipose tissue of women $(P<0.05$; Fig. 1$)$. It was noted that for equal quantities of RNA loaded onto the gels, levels of actin mRNA were $16 \%$ lower $(3,243+821[\mathrm{OM}]$ vs. $4,071+923$ [SQ] arbitrary densitometry units; $P<0.05$ ) in OM adipose tissue of women. Thus, the ratio of LPL to actin mRNA slightly underestimates the actual depot difference in LPL mRNA expression. Levels of LPL mRNA, relative to the total amount of total RNA, were $50 \%$ lower in the OM compared with the SQ depots of women. Densitometry of Northern blots showed a significant depot difference in women $(3,848 \pm 821$ [SQ] and 1,794 \pm 901 [OM] arbitrary units; $n=11 ; P<0.01)$. No consistent depot differences were noted in the men. 
Depot differences in hormonal effects on LPL activity. To investigate possible gender- and site-related differences in LPL activity, adipose tissue from men and women was cultured with or without $7 \mathrm{nM}$ Ins, in the presence or absence of $25 \mathrm{nM}$ dexamethasone (Dex; Fig. 2). In agreement with our previous results in SQ abdominal adipose tissue of women (23), Ins stimulated LPL activity approximately fivefold $(P<0.001)$, dexamethasone produced a smaller (two- to threefold) increase (statistically significantly only in the women $[P<0.001]$ ), and the effects of the two hormones added together were synergistic. There were no gender-related differences in responsiveness to Ins or Ins plus dexamethasone in the abdominal depot. In contrast, Ins produced only a small increase in LPL activity (twofold) in the OM depot of women $(P<0.005)$, and had no effect in the OM depot of men. Also, in the OM depot of both genders, the Dex-stimulated LPL activity was higher than Insstimulated LPL activity (Dex $>$ Ins in OM; $P \leq 0.001$, both genders; Ins $>$ Dex in SQ; $P<0.02$, both genders). Several gender differences were noted when results in OM adipose tissue from men and women were compared. LPL activity induced by $25 \mathrm{nM}$ Dex was significantly higher in the OM com-

\section{OMENTAL ADIPOSE TISSUE}

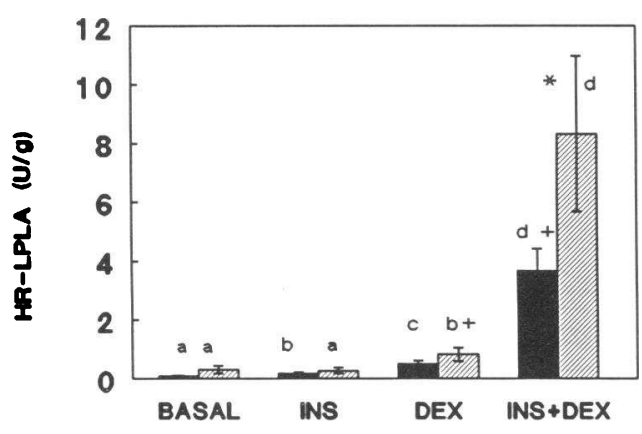

ABDOMINAL SUBCUTANEOUS

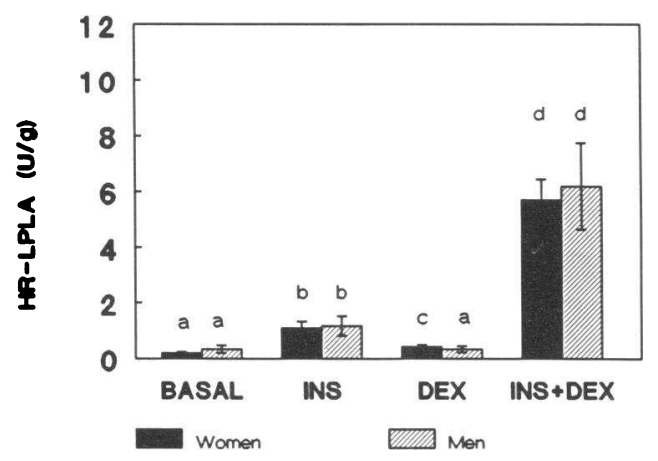

Figure 2. Effects of Ins and Dex (25 nM) on LPL activity in OM and SQ adipose tissues of men and women. Adipose tissue fragments were placed in organ culture for $7 \mathrm{~d}$ with no additions $(B A S A L)$, insulin (INS; $7 \mathrm{nM}$ ), dexamethasone ( $D E X ; 25 \mathrm{nM}$ ), or insulin plus dexamethasone $(I N S+D E X)$. Heparin-releasable LPL activity was then assayed. Data are the mean \pm SEM for 44 women and 17 men. Significant site differences (overall $\mathrm{F}_{1,8}=50, P<0.001$ ) were noted and differences between individual means were determined by post hoc $t$ tests $\left({ }^{*} P<0.01\right)$. Values for men and women were compared by independent t-tests $\left({ }^{+} P<0.05\right)$. Within each sex, bars with different letters are different from each other.

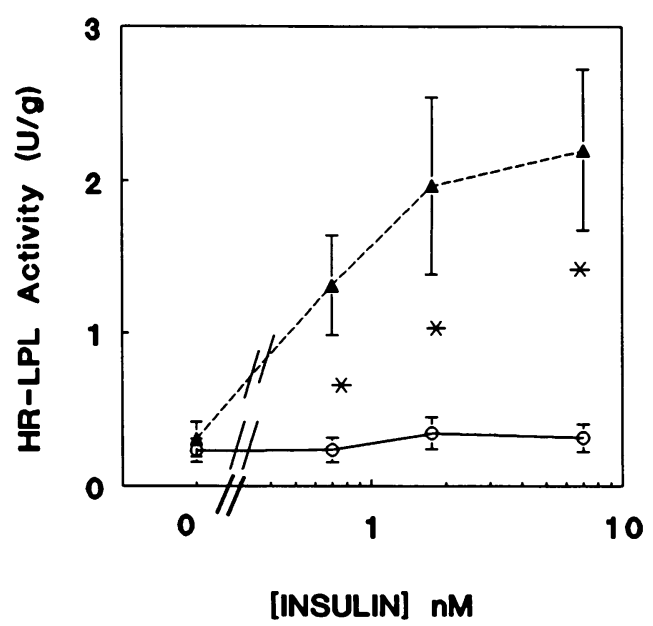

Figure 3. Ins effect on LPL activity in OM and SQ adipose tissues. Adipose tissues from the OM or SQ depots were obtained from the same patients $(n=11)$ and cultured with varying doses of Ins for 7 d. Values of $\mathrm{OM}(-\mathrm{O}-)$ were significantly lower than SQ $(--\Delta--)$ ( site $\times$ dose interaction $\left.\mathrm{F}_{2,27}=4.1, P<0.02\right)$ at each dose of Ins (Ins effect: $\mathrm{F}_{1,9}=11.6, P<0.01 ; P<0.01$ at each dose of Ins vs. basal in SQ by post hoc $t$ tests).

pared with the SQ adipose tissue of men. LPL activity achieved in the presence of $7 \mathrm{nM}$ Ins plus $25 \mathrm{nM}$ Dex was significantly lower in the OM than SQ depots of women, whereas no depot difference was apparent in men.

Insulin effects on LPL activity and LPL MRNA levels in $O M$ and $S Q$ adipose tissues. To determine whether sensitivity to Ins effects on LPL differed as a function of gender or depot, adipose tissues were cultured for $1 \mathrm{wk}$ in the presence of varying concentrations of Ins. There was no significant effect of gender, so dose-response curves for Ins effects on LPL in OM and SQ adipose tissue were combined (Fig. 3). In agreement with previous results, Ins caused a dose-dependent increase in LPL activity, with an average of $\sim 10$-fold over basal in abdominal SQ adipose tissue (23) (Fig. 3). A dose of $0.7 \mathrm{nM}$ Ins ( 100 $\mu \mathrm{U} / \mathrm{ml}$ ) produced greater than half-maximal stimulation. In contrast, over the range of doses tested, Ins did not stimulate

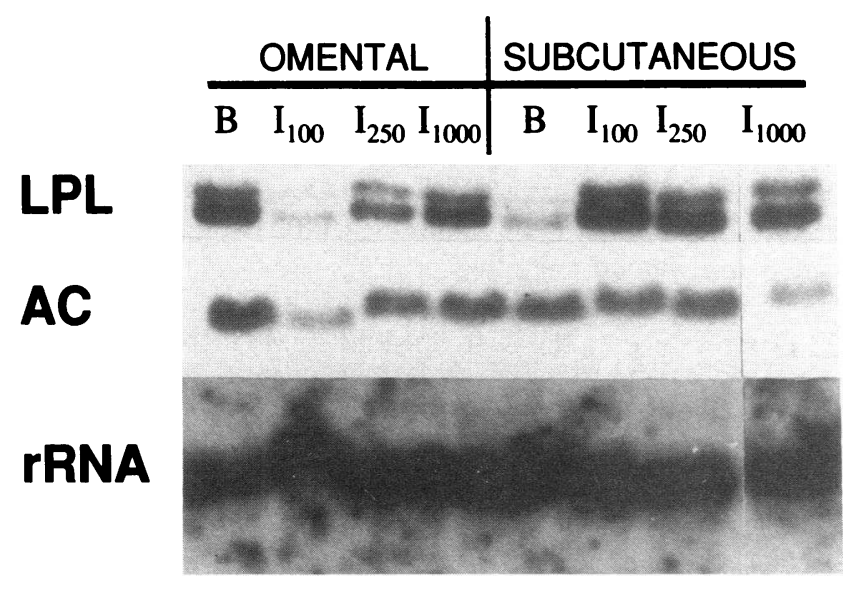

Figure 4. Effect of Ins on levels of LPL mRNA in OM and SQ adipose tissues. Adipose tissues were cultured as described in the legend to Figs. 1 and 3. Northern blots were probed with cDNAs to LPL, actin $(A C)$ and $28 \mathrm{~S}$ ribosomal RNA ( $r R N A)$. Autoradiograph shown is typical of three independent experiments. 
Table II. Effects of Insulin and Dexamethasone on LPL and Actin mRNA Levels in Adipose Tissue Cultured in the Absence or Presence of Varying Concentrations of Insulin and Dexamethasone

\begin{tabular}{lcccccc}
\hline & Basal & Insulin & Dex $(2.5 \mathrm{nM})$ & Dex $(25 \mathrm{nM})$ & Ins + Dex $(2.5 \mathrm{nM})$ & Ins + Dex $(25 \mathrm{nM})$ \\
\hline Omental & & & & & & \\
$\quad$ LPL & $676 \pm 236^{*}$ & $874 \pm 253^{*}$ & $2,468 \pm 521^{\mathrm{b}}$ & $2,783 \pm 778^{\mathrm{b}}$ & $1,597 \pm 404^{\mathrm{b}}$ & $4,653 \pm 789^{\mathrm{c} \neq}$ \\
$\quad$ Actin & $3,823 \pm 119$ & $4,850 \pm 810$ & $4,741 \pm 623$ & $3,613 \pm 508$ & $4,575 \pm 390$ & $3,108 \pm 580$ \\
Subcutaneous & & & & & & \\
$\quad$ LPL & $1,335 \pm 371^{\mathrm{a}}$ & $2,164 \pm 324^{\mathrm{b}}$ & $2,526 \pm 464^{\mathrm{b}}$ & $1,490 \pm 253^{\mathrm{a}, \mathrm{b}}$ & $6,188 \pm 1,530^{\mathrm{c}}$ & $5,753 \pm 893^{\mathrm{c}}$ \\
Actin & $3,841 \pm 638^{\mathrm{a}}$ & $2,534 \pm 370^{\mathrm{a}}$ & $3,117 \pm 314^{\mathrm{b}}$ & $2,014 \pm 301^{\mathrm{b}}$ & $2,969 \pm 381^{\mathrm{b}}$ & $1,864 \pm 376^{\mathrm{a}, \mathrm{b}}$ \\
& & & & & & \\
\hline
\end{tabular}

Values in arbitrary units derived from laser scanning densitometry of autoradiograms of Northern blots. Data are means \pm SEM of 10 subjects $(6$ women and $4 \mathrm{men})$, except values for Dex (2.5 nM) \pm insulin, where there were 6-7 subjects (3-4 women and 2-3 men). Northern blots were verified to have equal loading of total RNA $(5 \mu \mathrm{g})$ per lane by visual inspection of photos of ethidium bromide stained gels. Mean fat cell sizes were $0.47 \pm 0.07$ (omental) and $0.62 \pm 0.05$ (subcutaneous), $P<0.05$. Values within each depot with differing superscripts are significantly different from each other, $P<0.05$ by post-hoc paired $t$ tests. ${ }^{*}$ Value for omental significantly less than subcutaneous, paired $t$ test, $P<0.05$.

* Value lower than SQ, only among women $(n=6) P<0.05$.

LPL activity in OM adipose tissue. As shown in Fig. 2, when a larger number of subjects was studied, Ins caused a small but statistically significant increase over basal in LPL activity in OM adipose tissue of women, but not men.

In SQ adipose tissue, Ins increased the level of LPL mRNA relative to total RNA, while actin levels were not altered (Fig. 4 and Table II). However, in OM adipose tissue, Ins did not affect LPL mRNA levels. The constant amounts of ribosomal RNA per lane show that the equal amounts of RNA were loaded in each lane of the gels and the increase in LPL mRNA levels are specifically increased relative to total RNA (Fig. 4). Levels of LPL mRNA in the absence and presence of Ins were significantly greater in SQ than OM adipose tissue (Table II).

Dex effects on LPL activity and LPL $m R N A$ levels in OM and $S Q$ adipose tissues. Significant effects of Dex were obtained in OM adipose tissue of men and women $(P<0.01$; Fig. $5)$. In OM, Dex produced a dose-dependent, approximately threefold stimulation of LPL activity that was maximal at a concentration of $25 \mathrm{nM}$. At $25 \mathrm{nM}$ Dex, LPL activity was significantly higher in OM than SQ adipose tissue $(P<0.01$ in men and women ). Although the ANOVA indicated no interactions involving gender, post hoc $t$ tests failed to detect a significant Dex effect at any dose tested in SQ adipose tissue of men, in agreement with data on a larger number of subjects tested at 25 nM (see Fig. 2). In women, effects of Dex on SQ LPL activity were statistically significant at doses of $\geq 0.25 \mathrm{nM}(P<0.05)$. It is also noteworthy that a high dose of Dex $(250 \mathrm{nM})$ resulted in lower LPL activity than $25 \mathrm{nM}(P<0.02)$ in the OM depot of men and women.

Paralleling depot differences in LPL activity, 2.5 and 25 $n M$ Dex produced a three- to fourfold (OM) increase in LPL mRNA levels (Fig. 6 and Table II). In SQ adipose tissue, only $2.5 \mathrm{nM}$ Dex increased LPL mRNA levels.

Dex effects in the presence of Ins on LPL activity in $O M$ and $S Q$ adipose tissues. There were no significant effects of gender determined by ANOVA. The two depots responded differently when varying concentrations of Dex were added in the presence of a maximally stimulating dose of Ins (Fig. 7). At 7 nM Ins, Dex produced a dose-dependent increase in LPL activity in both depots, but the curve for OM was significantly shifted to the right. LPL activities at intermediate doses of Dex in the
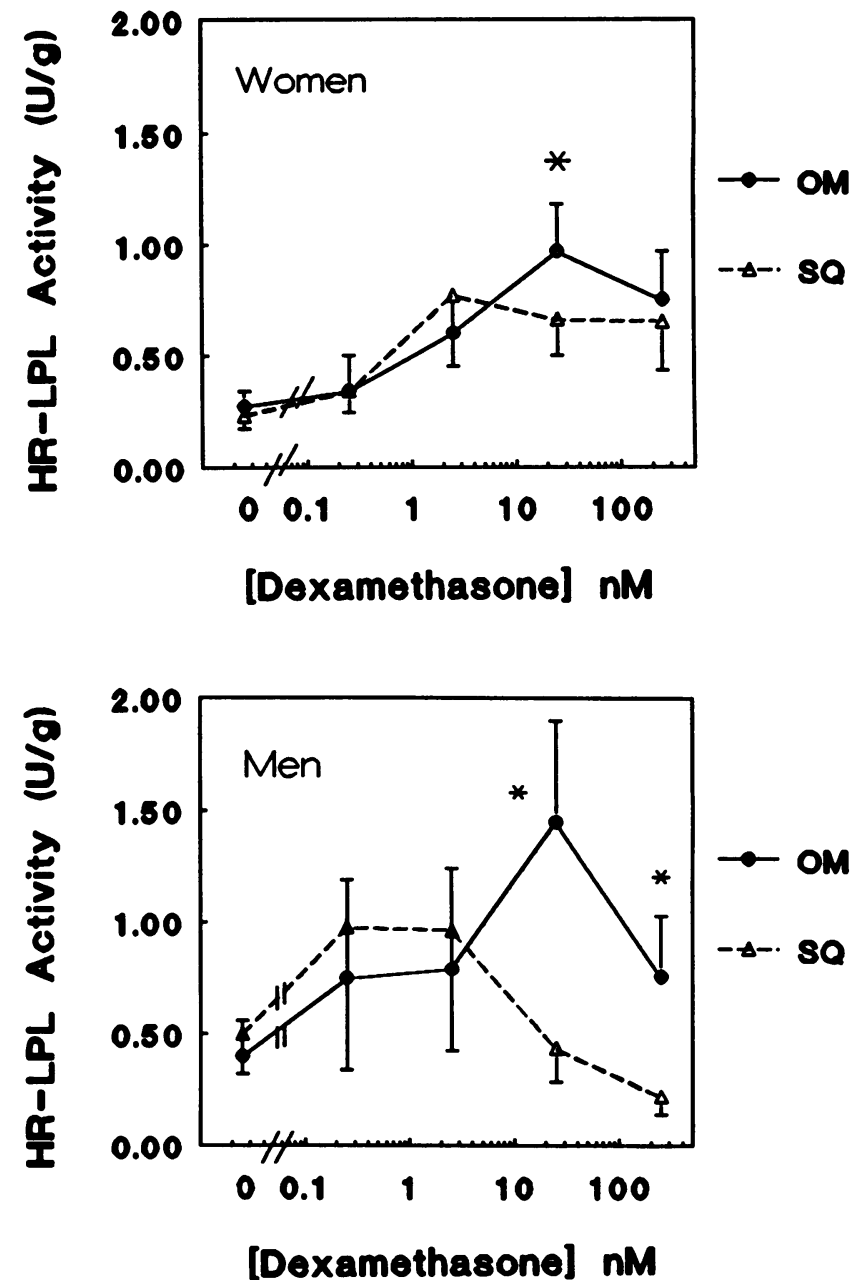

Figure 5. Effect of Dex on LPL activity in the OM and SQ adipose tissue of men and women. Adipose tissue, taken from the same patients, was cultured with varying concentrations of Dex for $7 \mathrm{~d}$. LPL activity and the presence of Dex effects were significantly greater than basal (dex effect: $F_{3,27}=5.5, P<0.005$ by ANOVA), at concentrations of $\geq 2.5 \mathrm{nM}(P<0.05$, post hoc $t$ tests $)$, except in the SQ depot of men ( site $\times$ dex interaction: $\mathrm{F}_{3,27}=6.55, P<0.005$ ). ${ }^{*}$ Significant difference between sites within each sex. 


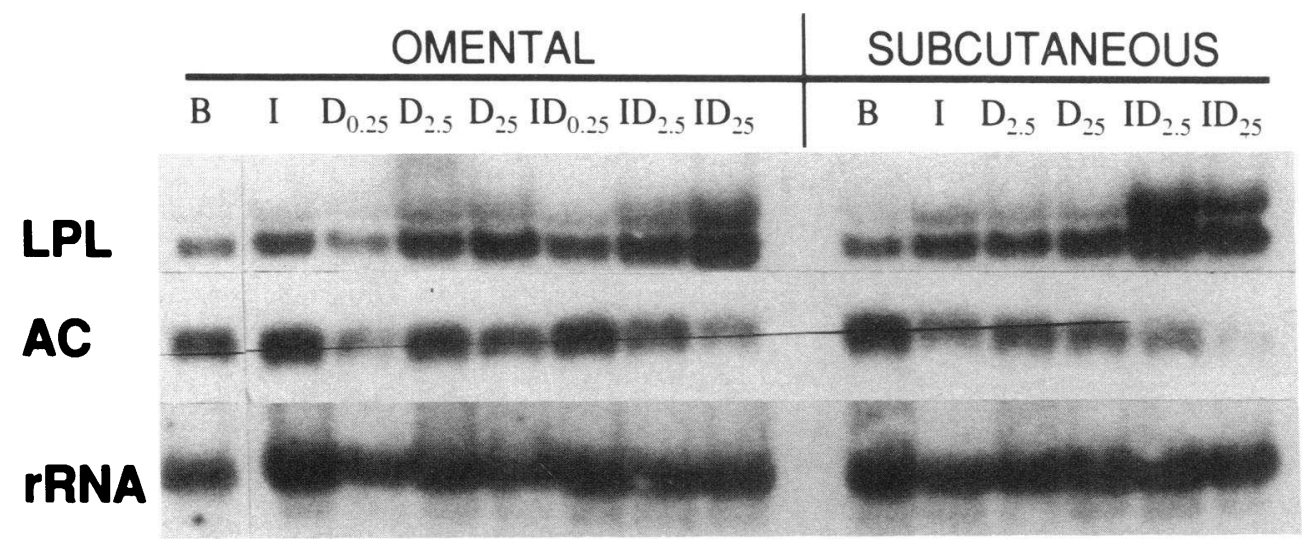

Figure 6. Levels of LPL mRNA in $\mathrm{OM}$ and $\mathrm{SQ}$ adipose tissue cultured with varying concentrations of Dex $\left(D_{0.25-250 \mathrm{nM}}\right)$ in the absence or presence of Ins. Data are from RNA extracted from cultured adipose tissues of an obese man. Tissue was cultured as described in the legend to Figs. 2 and 5 , and blots were probed as described in the legend to Fig. 4. Autoradiographes are representative of those used to calculate mean values in Table II.

presence of Ins were significantly higher in SQ than OM adipose tissue. Because the initial Ins-stimulated LPL activities differed between the depots, absolute increments above Insstimulated values were calculated to compare relative Dex effects. At $0.25 \mathrm{nM}$ Dex, increments were $0.35 \pm 0.19(\mathrm{OM})$ and $2.42 \pm 0.9$ (SQ) $\mathrm{U} / \mathrm{g}$ and at $2.5 \mathrm{nM}$, increments were $2.56 \pm 0.8$ $(\mathrm{OM})$ vs. $5.19 \pm 1.4$ (SQ) $\mathrm{U} / \mathrm{g}$ (both site differences were $P$ $<0.02$ by paired $t$ tests). Thus, compared with OM adipose tissue, SQ adipose tissue was more responsive to effects of submaximal concentrations of Dex added in the presence of Ins.

Greater sensitivity of SQ adipose tissue to interactive effects of Ins and Dex was also expressed at the level of LPL mRNA (Figs. 6 and 7 and Table II). In SQ adipose tissue, a significant increase in LPL mRNA, relative to total RNA, was obtained with $2.5 \mathrm{nM}$ Dex plus $7 \mathrm{nM}$ Ins compared with values in the presence of either hormone alone, whereas no increase was seen in OM adipose tissue. When $25 \mathrm{nM}$ Dex was added with Ins $(7 \mathrm{nM})$, increases in LPL mRNA over those seen in the presence of Ins or Dex alone were apparent in both depots. A decreased expression of actin mRNA was observed only in SQ adipose tissue cultured with Ins and $25 \mathrm{nM}$ Dex (Table II).

LPL $m R N A$ in isolated fat cells. To confirm that effects of Ins and Dex on LPL mRNA were expressed at the level of the fat cell, rather than only in other cells present in intact tissue fragments, RNA was extracted from fat cells isolated by collagenase digestion of cultured adipose tissue fragments. As shown in Fig. 8, both Ins and Dex increased adipocyte LPL mRNA in fat cells isolated from cultured OM adipose tissue. When the hormones were added in combination, no synergism was seen. In fat cells from cultured SQ adipose tissue, levels of LPL mRNA were several-fold higher in samples cultured with Ins plus Dex compared with Ins alone, paralleling levels of LPL mRNA measured in RNA extracted from the intact adipose tissue (Fig. 7 and Table II).

LPL synthesis. To confirm that changes in LPL mRNA were paralleled by changes in LPL synthesis, biosynthetic labeling and immunoprecipitation were carried out in two patients, and a typical result is shown in Fig. 9. In abdominal SQ adipose tissue, in agreement with our previous data in SQ adipose tissue (23), Ins increased LPL synthesis while Dex alone did not alter LPL synthesis. The combination of Ins and Dex, compared with Ins alone, increased LPL synthesis up to several-fold in some patients (Fig. 6) (23). In contrast, in OM adipose tissue, LPL synthesis was not affected by Ins, but it was increased by
Dex, as expected from effects of these hormones on levels of LPL mRNA. The combination of Ins and Dex did not further increase LPL synthesis in OM adipose tissue.
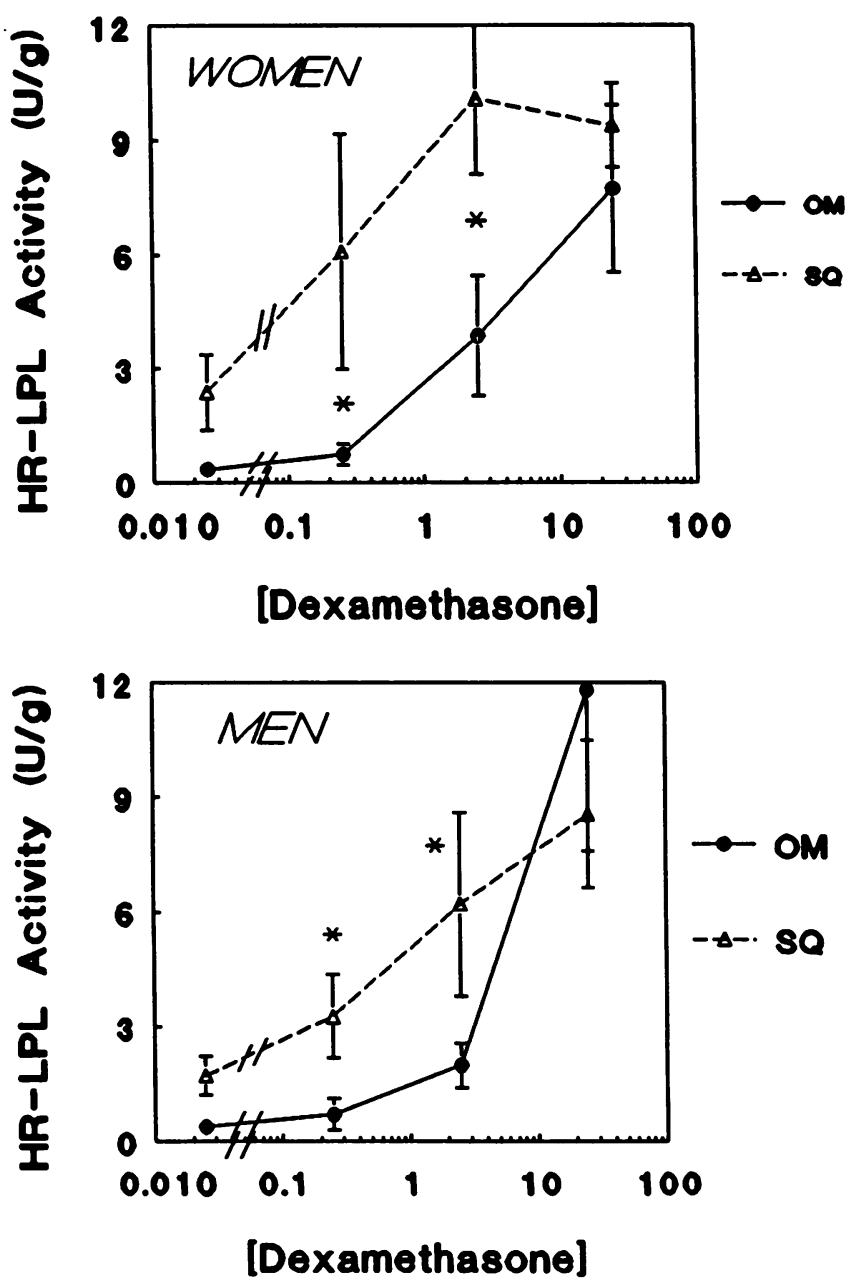

Figure 7. Effects of varying doses of Dex (nM), in the presence of 7 $\mathrm{nM}$ Ins, on LPL activity in the OM and SQ adipose tissues. Adipose tissue fragments were cultured as described in the legend to Fig. 1. Significant increases in activity were obtained at doses of $\geq 2.5 \mathrm{nM}$ $(P<0.05$, post hoc $t$ tests $)$ in OM adipose tissue from men and women, and SQ adipose tissue from women. 


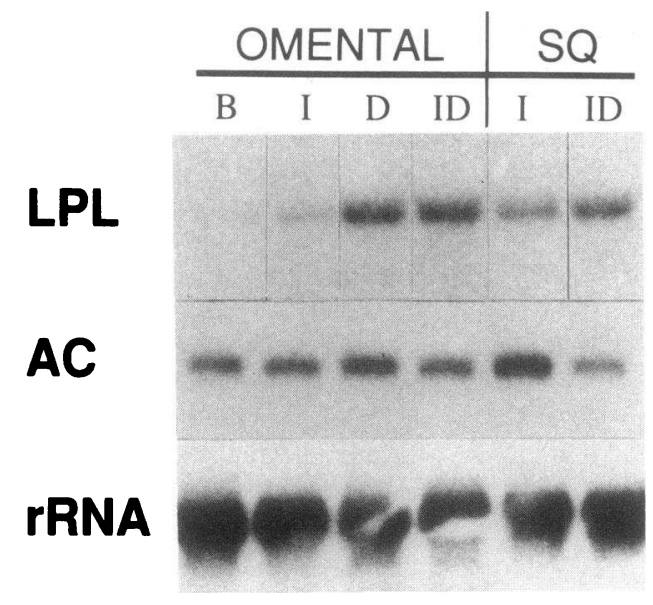

Figure 8. Levels of LPL mRNA, relative to actin, in adipocytes isolated from cultured human adipose tissue. Adipose tissues from the $\mathrm{OM}$ and SQ depots of an obese woman were cultured as described in the legend to Fig. 2. Data are representative of two independent experiments.

\section{Discussion}

Variations in fat cell size and LPL activity among different anatomical fat depots have been well documented in the literature $(7,11,12,28)$. Regional differences are most prominent in women, and occur even in severe obesity (11). For instance, fat cells in the OM depot of severely obese women remain smaller and have lower LPL activity than SQ fat cells (11). The present studies provide a possible molecular basis for these differences by demonstrating variations in the expression of LPL mRNA in OM and SQ adipose tissue of women, but not men. Differential sensitivity to Ins and glucocorticoids effects on LPL regulation in human OM and SQ adipose tissues were also demonstrated in vitro, and these may contribute to observed differences in vivo. Because depot differences in the hormonal regulation of LPL were observed after long-term culture in vitro, these data are consistent with the concept that SQ and visceral adipose tissues are intrinsically different.

A striking finding was that OM adipose tissue, a visceral depot, is resistant to Ins effects on LPL activity, while adipose tissue from the abdominal SQ site is highly responsive to physiological concentrations of Ins. In abdominal SQ adipose tissue, Ins-induced increases in LPL activity were paralleled by increases in the level of LPL mRNA, and, in agreement with our previous results (11), increased LPL synthesis. No consistent effects of Ins on LPL mRNA, synthesis, or activity were observed in the OM adipose tissue.

Depot differences in Ins action on LPL may explain a discrepancy in the literature with regard to the ability of Ins to regulate LPL in human adipocytes in vitro. Studies failing to obtain effects of physiological doses of Ins on LPL used primary cultures of collagenase-isolated adipocytes from the OM fat depot $(22,29)$. Further investigation is required to determine whether Ins would affect LPL in isolated abdominal adipocytes, or whether paracrine factors are also involved.

The present data also demonstrate that the ability of Ins to increase LPL activity and synthesis in cultured human adipose tissue is due to increases in steady-state levels of LPL mRNA.
This result is in agreement with data in isolated rat adipocytes showing that increases in LPL mRNA were due to a stabilization of the mRNA rather than an increase in transcription (30). The mechanisms involved in human adipose tissue will require further investigation.

The decreased ability of Ins to stimulate LPL in OM adipose tissue is consistent with the insensitivity of this tissue to the antilipolytic effect of Ins (14). Thus, the lower LPL in OM adipose tissue may be a general feature of an overall Ins resistance. The molecular mechanisms involved are not known, but the observed difference in Ins action on LPL gene expression in $\mathrm{OM}$ and $\mathrm{SQ}$ adipose tissue provides an interesting model for dissecting tissue-specific factors governing Ins responsiveness.

These data also confirm and extend our previous report that glucocorticoids are important regulators of human adipose tissue LPL (23). Dex alone produced only small increments in LPL activity in the SQ adipose tissue of women. This effect was less apparent in the SQ adipose tissue of men. In marked contrast, $\mathrm{OM}$ adipose tissue of both men and women was highly responsive to stimulatory effects of Dex on LPL activity. Increases in LPL activity in adipose tissue cultured with Dex were largely explained by the ability of this hormone to increase levels of LPL mRNA. These data agree well with reports of higher numbers of glucocorticoid receptors in OM compared with SQ adipose tissues $(32,33)$.

Synergistic effects of combinations of Ins and Dex were also observed in both fat depots. Sensitivity to submaximal doses of Dex, in the presence of a maximal Ins concentration, was higher in the SQ depot of men and women. The increased sensitivity of the SQ adipose tissue to Dex in the presence of Ins may reflect the greatly increased responsiveness of this tissue to Ins, as no differential sensitivity to submaximal concentrations of Dex alone was apparent in the two tissues (Fig. 5).

Maximally induced levels of LPL activity and LPL mRNA ( $7 \mathrm{nM}$ Ins plus $25 \mathrm{nM}$ Dex) were greater in the SQ than OM depot of women, but were similar in men. The lower maximal expression of LPL activity in cultured OM adipose tissue of women is in good agreement with previous findings of lower LPL activity (11) and LPL mRNA levels (present results) observed in OM compared with SQ adipose tissue of women. Thus, differences in responsiveness to effects of Ins and glucocorticoids on LPL may play a role in controlling regional variations in LPL activity.

The lower activity of LPL activity in OM adipose tissue of women must be considered relative to the smaller size of the fat cells in this depot. The difference in activity persists whether the data are calculated on a per cell or per fat cell surface area basis $(11,16)$. Because recovery of RNA cannot be quantified,

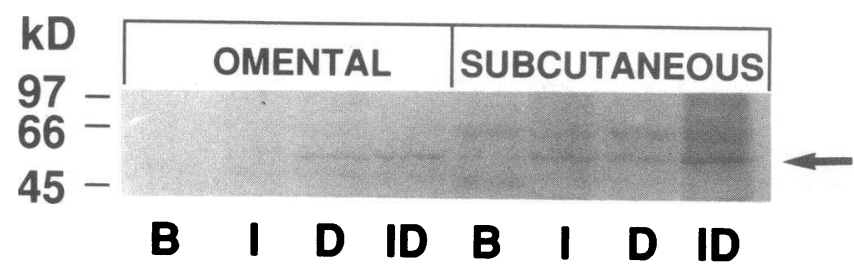

Figure 9. Rates of LPL synthesis in cultured human adipose tissue. Adipose tissues from the same patient were cultured as described in the legend to Fig. 1, pulse labeled for $30 \mathrm{~min}$ with $\left[{ }^{35} \mathrm{~S}\right]$ methionine and $\left[{ }^{35} \mathrm{~S}\right]$ cysteine, and immunoprecipitated. Shown is a fluorograph that was typical of two independent experiments. 
it is impossible to calculate LPL mRNA per cell, and it is difficult to determine whether observed changes in LPL mRNA levels fully account for observed differences in activity (11). Nevertheless, it is clear that changes in the relative abundance of LPL mRNA occur, indicating that specific changes in the expression of this gene occur both in vivo, as indicated by the results in fresh samples of adipose tissue, and in vitro under the influence of specific hormones.

It is also difficult to determine whether the magnitude of the increases in LPL mRNA in the presence of specific hormones can account for the observed variations in heparin-releasable LPL activity. Ins increased the specific expression of LPL mRNA relative to total RNA an average of twofold. However, the apparent yield of RNA was also increased by about twofold in the presence of Ins (our unpublished observation), so that the combination of specific and nonspecific increases in LPL mRNA appear to account for the increases in LPL activity. Dex did not affect apparent yield, and the specific increase in LPL mRNA relative to total RNA appears to account for the increase in LPL synthesis and activity. In the presence of Ins plus Dex, LPL mRNA levels were only two- to fourfold higher than in the presence of Ins alone. The magnitude of this increase in LPL mRNA is in good agreement with the maximum of 2-3-fold stimulations of LPL synthesis, but is insufficient to explain observed increases ( 5-10-fold) in LPL activity in the presence of maximal concentrations of Ins and Dex. Thus, changes in posttranslational LPL regulation, possibly variations in responsiveness to the ability of Dex to decrease the rate of LPL degradation (23), may also play an important role in depot differences in LPL.

To assess whether hormone-induced variations in LPL mRNA levels were due to changes at the level of the adipocyte, rather than other cells present in adipose tissue fragments, we isolated RNA from isolated fat cells prepared from cultured adipose tissue. Similar increases in LPL mRNA were seen in RNA isolated from fat cells and tissue, showing that LPL expression in the mature adipocytes is affected. Levels of LPL mRNA in the stromal vascular (non-fat cell) fraction are only a small percentage of levels in adipocytes in subcutaneous tissue (7). We have also recently reported that LPL expression is very low in the non-fat cell fraction of cultured OM and SQ adipose tissues ( $<5 \%$ of fat cell expression) (34). Thus, the changes in adipose tissue LPL mRNA levels observed during culture of adipose tissue are not due to hormone-induced differentiation of preadipocytes that could exist within the tissue.

Dex increased LPL activity and mRNA in OM adipose tissue (and to a lesser extent in SQ adipose tissue of women). This result is opposite of a report by Ong et al. (35), who found that Dex actually decreased LPL mRNA levels and activity in rat adipocytes, and that there was no synergism between effects of Ins and Dex. The explanation for this may lie in species differences or paracrine interactions within adipose tissue.

Regional differences in the expression of mRNAs encoding LPL (7), beta adrenergic receptors (9), and glucocorticoid receptors $(8)$ have also been demonstrated between human subcutaneous abdominal and gluteal adipose tissues. Thus, it is clear that adipose tissue is a heterogeneous organ. Moreover, the data presented here show that such depot differences persist after long-term culture, and may be due to variations in responsiveness to specific hormonal effects. Therefore, regional differences in adipocyte metabolism are not likely to be simply secondary to depot differences in the in vivo milieu (blood flow, innervation ). In addition, the lower LPL mRNA expression in $\mathrm{OM}$ adipose tissue of women is apparently specific, as it is apparent relative to total RNA, and the expression of at least one other specific mRNA, for the glucocorticoid receptor, is increased (32).

A recent report suggested that the extent of trimming of LPL oligosaccharides differs between human OM and SQ adipose tissues (36). Since no activity data were given, and the sex of the patients was not specified, the importance of these changes is unclear. It is possible that differential responses to hormonal effects on LPL activity are in part due to altered processing of LPL.

The present data suggest an important role for glucocorticoids in the regulation of LPL in human adipose tissue. The observation by Rebuffe-Scrive et al. (18), that LPL activity is increased in the abdominal SQ adipose tissue (but not thigh fat) of patients with Cushing syndrome, supports the relevance of these findings in organ culture to the in vivo situation. No data are currently available on the expression of LPL in the OM depot of Cushing patients.

Some caution must be used in extrapolating the present findings using adipose tissue from severely obese subjects to adipose tissue from lean or more moderately obese subjects. Differences in the replicative capacity and mitogenic protein production of adipocyte precursors from severely obese compared with lean subjects have been reported (37). However, because the pattern of depot differences in LPL activity, fat cell size, and other metabolic variables are similar in severely obese subjects and moderately obese or lean subjects $(11,12,16,18$, 28,38 ), it is unlikely that the present findings are unique to very obese patients. Furthermore, similar results were obtained in formerly obese subjects ( $n=6$; data not shown) that were included in the present study so that the depot differences observed here are not likely to be simply secondary to the obesity.

In summary, OM and SQ adipose tissues from obese subjects differ in sensitivity and responsiveness to effects of Ins and glucocorticoids on LPL gene expression, LPL synthesis, and LPL activity. These differences could arise by the depot-specific expression of "tissue-specific" regulatory factors, in a manner analogous to differences in LPL regulation in adipose tissue and muscle (10). Regardless of the molecular mechanisms involved, the present data suggest that regional variations in the hormonal regulation of LPL among adipose tissues contribute to in vivo variations in enzyme activity. Enhanced responsiveness to glucocorticoid effects in OM adipose tissue may contribute to increased visceral fat deposition in upper body obese women who show increased cortisol turnover (39), and in patients with Cushing syndrome. Relative resistance to the synergistic effects of Ins and glucocorticoids on OM compared with the SQ adipose tissue of women may underlie the decreased expression of LPL activity and mRNA in this depot. These differences in the hormonal regulation of LPL may play a role in modulating regional deposition of fat in humans.

\section{Acknowledgments}

We thank Kelly Przybysz for her assistance with RNA preparation and Lori Gillar for manuscript preparation.

This work was supported by National Institutes of Health grant DK-43422 and grants from the New Jersey Affiliate of the American Heart Association and the New Jersey Agricultural Experiment Station (D-14155-1-93). 


\section{References}

1. Despres, J. P., S. Moorjani, P. J. Lupien, A. Tremblay, A. Nadeau, and C. Bouchard. 1990. Regional distribution of body fat, plasma lipoproteins and cardiovascular disease. Arteriosclerosis. 10:497-511.

2. Kvist, H., B. Chowdhury, U. Grangard, U. Tylen, and L. Sjostrom. 1989. Total and visceral adipose-tissue volumes derived from measurements with computed tomography in adult men and women: predictive equations. Am. J. Clin. Nutr. 48:1351-1361.

3. Ashwell, M., T. J. Cole, and A. K. Dixon. 1985. Obesity: new insight into the anthropometric classification of fat distribution shown by computed tomography. Br. Med. J. 290:1692-1694.

4. Peiris, A. N., M. S. Sothmann, G. Hoffmann, M. I. Hennes, C. R. Wilson, B. Gustafson, and A. H. Kissebah. 1989. Adiposity, fat distribution, and cardiovascular risk. Ann. Int. Med. 110:867-872.

5. Fujioka, S., Y. H. Matusuzawa, K. Talunaga, and S. Tarui. 1987. Contribution of intra-abdominal fat accumulation to the impairment of glucose and lipid metabolism in human obesity. Metabolism. 36:54-59.

6. Leibel, R. L., N. K. Edens, and S. K. Fried. 1989. Physiologic basis for the control of body fat distribution in humans. Annu. Rev. Nutr. 9:417-443.

7. Arner, P., H. Lithell, H. Wahrenberg, and M. Bronnegard. 1991. Expression of lipoprotein lipase in different human subcutaneous adipose tissue regions. J. Lipid Res. 32:423-429.

8. Bronnegard, M., P. Arner, L. Hellstrom, G. Akner, and J.-A. Gustafsson 1990. Glucocorticoid receptor messenger ribonucleic acid in different regions of human adipose tissue. Endocrinology. 127:1689-1696.

9. Arner, P., H. Wahrenberg, and M. Bronnegard. 1990. Beta-adrenoreceptor expression in human fat cells from different regions. J. Clin. Invest. 86:15951600.

10. Eckel, R. H. 1989. Lipoprotein lipase: a multifunctional enzyme relevant to common metabolic diseases. N. Engl. J. Med. 320:1060-1068.

11. Fried, S. K., and J. G. Kral. 1987. Sex differences in regional distribution of fat cell size and liprotein lipase activity in morbidly obese patients. Int. J. Obes. 11:129-140.

12. Lithell, H., and J. Boberg. 1979. The lipoprotein lipase activity of adipose tissue from different sites in obese women. Relationship to cell size. Int. J. Obes. 2:47-52.

13. Zechner, R. 1990. Rapid and simple isolation procedure for lipoprotein lipase from human milk. Biochim. Biophys. Acta. 1044:20-25.

14. Bolinder, J., L. Kager, J. Ostman, et al. 1983. Differences at the receptor and postreceptor levels between human omental and subcutaneous adipose tissue in the action of insulin on lipolysis. Diabetes. 32:117-123.

15. Rebuffe-Scrive, M., K. Lundholm, and P. Bjorntorp. 1985. Glucocorticoid hormone binding to human adipose tissue. Eur. J. Clin. Invest. 15:267-271

16. Rebuffe-Scrive, M., B. Andersson, L. Olbe, and P. Bjorntorp. 1989. Metab olism of adipose tissue in intraabdominal depots of nonobese men and women. Metabolism. 38:453-458.

17. Mayo-Smith, W., C. W. Hayes, B. M. K. Biller, A. Klibanski, H. Rosenthal, and D. I. Rosenthal. 1989. Body fat distribution measured with CT: correlations in healthy subjects, patients with anorexia nervosa, and patients with Cushing Syndrome. Radiology. 170:515-518.

18. Rebuffe-Scrive, M., M. Krotkiewski, J. Elfverson, and P. Bjorntorp. 1988. Muscle and adipose tissue morphology and metabolism in Cushing's syndrome. J. Clin. Endocrinol. \& Metab. 67:1122-1128.

19. Kern, P. A., J. M. Ong, B. Saffari, and J. Carty. 1990. The effects of weigh loss on the activity and expression of adipose tissue lipoprotein lipase in very obese humans. N. Engl. J. Med. 322:1053-1059.

20. Kern, P. A., J. M. Ong, and J. W. F. Goers. 1988. Regulation of lipoprotein lipase immunoreactive mass in isolated human adipocytes. J. Clin. Invest $81: 398-406$
21. Ong, J. M., and P. A. Kern. 1989. Effect of feeding and obesity on lipoprotein lipase activity, immunoreactive protein and messenger RNA levels in human adipose tissue. J. Clin. Invest. 84:305-310.

22. Kern, P. A., S. Marshall, and R. H. Eckel. 1985. Regulation of lipoprotein lipase in primary cultures of isolated human adipocytes. J. Clin. Invest. 75:199208.

23. Appel, B., and S. K. Fried. 1992. Effects of insulin and dexamethasone on lipoprotein lipase in human adipose tissue. Am. J. Physiol. 262:E695-E699.

24. Fried, S. K., and R. Zechner. 1989. Effects of cachectin/tumor necrosis factor on human adipose tissue lipoprotein lipase activity, mRNA levels, and biosynthesis. J. Lipid Res. 30:1917-1923.

25. Chomzczynski, P., and N. Sacchi. 1987. Single-step method of RNA isolation by acid guanidinium thiocyanate-phenol-chloroform extraction. Anal. Biochem. 162:156-159.

26. Fried, S. K., I. J. Turkenkopf, I. J. Goldberg, M. H. Doolittle, T. G. Kirchgessner, M. C. Schotz, P. R. Johnson, and M. R. C. Greenwood. 1992. Mechanisms of increased lipoprotein lipase in fat cells of obese Zucker rats. Am. J. Physiol. 261:E653-E660.

27. Winer, B. J. 1971. Multifactor experiments having repeated measures on the same elements. In Statistical Principles in Experimental Design. McGrawHill Inc., New York. 514-603.

28. Rebuffe-Scrive, M., M. L. Enk, N. Crona, P. Lonnroth, L. Abrahamson, U. Smith, and P. Bjorntorp. 1985. Fat cell metabolism in different regions of women. Effect of menstrual cycle, pregnancy, and lactation. J. Clin. Invest. 75:1973-1976.

29. Kern, P. A., M. E. Svoboda, R. H. Eckel, and J. J. Van Wyk. 1989 Insulin-like growth factor action and production in adipocytes and endothelia cells from human adipose tissue. Diabetes. 38:710-717.

30. Raynolds, M. V., P. D. Awald, D. F. Gordon, A. Gutierrez-Hartmann, D. C. Rule, W. M. Wood, and R. H. Eckel. 1990. Lipoprotein lipase gene expression in rat adipocytes is regulated by isoproterenol and insulin through different mechanisms. Mol. Endocrinol. 4:1416-1422.

31. Lindberg, U. B., N. Crona, G. Silfverstolpe, P. Bjorntorp, and M. RebuffeScrive. 1990. Regional adipose tissue metabolism in postmenopausal women after treatment with exogenous sex steroids. Horm. Metab. Res. 22:345-351.

32. Rebuffe-Scrive, M., M. Bronnegard, A. Nilsson, J. Eldh, J.-A. Gustafsson and P. Bjorntorp. 1990. Steroid hormone receptors in human adipose tissues. $J$. Clin. Endocrinol. \& Metab. 71:1215-1219.

33. Miller, L. K., J. G. Kral, G. W. Strain, and B. Zumoff. 1988. Differential binding of dexamethasone to ammonium sulfate precipitates of human adipose tissue cytosols. Steroids. 49:507-522.

34. Russell, C., and S. K. Fried. 1993. Distribution of lipoprotein lipase activity and mRNA in cultured human adipose tissue. FASEB (Fed. Am. Soc. Exp Biol.) J. 7:A608.

35. Ong, J. M., R. B. Simsolo, B. Saffari, and P. A. Kern. 1992. The regulation of lipoprotein lipase gene expression by dexamethasone in isolated rat adipocytes. Endocrinology. 130:2310-2316

36. Sakayama, K., H. Masuno, H. Okumura, T. Shibata, and H. Okuda. 1992 Glycosylation of lipoprotein lipase in human subcutaneous and omental adipose tissues. Biochim. Biophys. Acta 1127:153-156.

37. Teichert-Kuliszewska, K., G. S. Hamilton, M. Deitel, and D. A. K. Roncari. 1992. Augmented production of heparin-binding mitogenic proteins by preadipocytes from massively obese persons. J. Clin. Invest. 90:1226-1231

38. Rebuffe-Scrive, M., B. Anderson, L. Olbe, and P. Bjorntorp. 1990. Metabolism of adipose tissue in intraabdominal depots in severely obese men and women. Metabolism. 39:1021-1025.

39. Marin, P., N. Darin, T. Amemiya, B. Andersson, S. Jern, and P. Bjorntorp. 1992. Cortisol secretion in relation to body fat distribution in obese premenopausal women. Metabolism. 41:882-886. 